\title{
Change in the hydraulic properties of a Brazilian clay Ferralsol on clearing for pasture
}

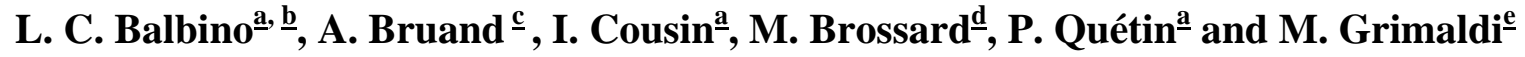 \\ ${ }^{a}$ INRA, Unité de Science du Sol, BP 20619, 45166 Olivet Cedex, France \\ ${ }^{b}$ EMBRAPA Arroz e Feijão, CP 179, CEP 75.375-000 Santo Antonio de Goiás, GO, Brazil \\ ${ }^{c}$ ISTO, Université d'Orléans, Géosciences, BP 6759, 45067, Orléans Cedex 2, France \\ ${ }^{d}$ IRD/EMBRAPA Cerrados, CP 7091, 71619-970, Brasilia, DF, Brazil \\ ${ }^{e}$ IRD/FCAP, CP 917, 66077-530, Bélem, PA, Brazil
}

\section{Abstract}

Ferralsols under native vegetation have a weak to moderate macrostructure and a welldeveloped microstructure corresponding to subrounded microaggregates that are usually 80 to $300 \mu \mathrm{m}$ in size. The aim of this study was to analyze how the hydraulic properties of a clay Ferralsol were affected by a change of structure when the native vegetation is cleared for pasture. We studied the macrostructure in the field and microstructure in scanning electron microscopy. The water retention properties were determined by using pressure cell equipment. We determined the saturated hydraulic conductivity, $K_{\mathrm{s}}$, by applying a constant hydraulic head to saturated core samples, and the unsaturated hydraulic conductivity, $K(\Psi)$, by applying the evaporation method to undisturbed core samples. Results showed a significant decrease in the water retained at -1 and $-10 \mathrm{hPa}$ from 0 - to $40-\mathrm{cm}$-depth when the native vegetation is cleared for pasture. That decrease in the water retained was related to a smaller development of microaggregation and greater proportion of microaggregates in close packing. For smaller water potential, there was no difference of water retained at every depth between native vegetation and pasture. Pedotransfer functions established earlier for Brazilian Ferralsols and using clay content as single predictor gave pretty good results but the precision of the estimation decreased when the water potential increased. This decrease in the precision was related to the lack of predictor taking structure into account. $K_{\mathrm{s}}$ and $K(\Psi)$ showed an upward trend with depth under native vegetation and pasture. Except at $0-7-\mathrm{cm}$ depth between the Brachiaria clumps in the pasture where smaller $K_{\mathrm{s}}$ and $K(\Psi)$ than at the other depth was recorded whatever land use, we did not record any significant difference of $K_{\mathrm{s}}$ and $K(\Psi)$ at every depth between native vegetation and pasture. The upward trend shown by the hydraulic conductivity with depth was related to the increase in the development of microaggregation with depth.

Author Keywords: Structure; Bulk density; Microaggregate; Hydraulic conductivity; Water retention; Pedotransfer function

\section{Introduction}

Ferralsols (ISSS Working Group R.B., 1998) that correlate to Latosols of the Brazilian soil classification (EMBRAPA, 1999) show little or no distinct horizonation and their macrostructure is weak to moderate. On the other hand, Ferralsols have typically a strong microstructure (Neufeldt et al., 1999 and Westerhof et al., 1999). Microaggregates are near spherical ranging from 80 to $300 \mu \mathrm{m}$ in size usually. They correspond to the 'pseudosand', 'micropeds', 'granules' described earlier by Kubiena (1950), Brewer (1964) and Trapnell and 
Webster (1986), respectively. Thus, Ferralsols porosity is closely related to the arrangement of microaggregates and the packing of clay particles within the microaggregates with a contribution of large pores resulting from biological activity.

The large biological pores and the pores that result from the arrangement of the microaggregates are preferentially affected by compaction when the soil is cleared and then cultivated (Stoner et al., 1991). Several studies showed that other pores than large biological pores alone are affected when the land is cleared for cultivation. Hartmann (1991) showed in Ivory Coast that microaggregation was affected by fertilization practices that induced kaolinite dispersion and consequently a collapse of the microaggregates. Chauvel et al. (1991) showed that after native Amazonian forest clearing, the packing of kaolinite particles within the microaggregates was affected by roots suction of the leguminous cropped. After cultivation, Tavares Filho (1995) and Assouline et al. (1997) recorded a decrease in the porosity that resulted from a change of the microaggregate arrangement both in the topsoil and subsoil. More recently, Balbino et al. (2001) studied Brasilian Ferralsols and showed a dramatic decrease in the porosity after 10 years of pasture but unlike Chauvel et al. (1991), they did not record any variation of the porosity within the microaggregates.

On the other hand, several authors studied the water retention properties (see Balbino et al., 2002a and Balbino et al., 2002b), the saturated hydraulic conductivity (e.g. Stone et al., 1994; Volpe, 1998; Ferreira et al., 1999 and Beutler et al., 2001 and the unsaturated hydraulic conductivity ( Stone and Silveira, 1978 and Frizzone and Sobrinho, 1982) of Brazilian Ferralsols but most studies did not associated any detailed description of the structure. The aim of this study is to analyze how the hydraulic properties of a clayey Brazilian Ferralsol are affected when the land is cleared for pasture and to discuss the results in relation to structure.

\section{Materials and methods}

\subsection{The soils}

The soils studied are located $30 \mathrm{~km}$ North of Planaltina de Goiás in the state of Goiás $\left(15^{\circ} 14^{\prime} \mathrm{S}, 47^{\circ} 42^{\prime} \mathrm{W}\right)$ in the Brazilian Savannah biome. These soils had a clay texture (Table 1$)$ and showed little horizonation, no macrostructure and a strong microstructure with nearspherical microaggregates (Balbino et al., 2001). They are Latossolo Vermelho according to the Brazilian classification (EMBRAPA, 1999), Ferralsols according to the ISSS Working Group R.B. (1998). The elevation is $825 \mathrm{~m}$. The climate is characterized by distinct wet and dry seasons, $80 \%$ to $90 \%$ of the annual rainfall occurring between October and April (Assad et al., 1993). Mean annual rainfall ranges from 1100 to $1200 \mathrm{~mm}$ with 4 to 6 months with no rain. The soils developed in fine textured and deeply weathered Meso-neoproterozoic metasedimentary rocks (Paranoá Group) that inherited from the erosion of Precambrian materials (Dardenne and Faria, 1986). 


\begin{tabular}{|c|c|c|c|c|c|c|}
\hline \multirow{2}{*}{$\begin{array}{l}\text { Depth } \\
(\mathrm{cm})\end{array}$} & \multirow{2}{*}{$\begin{array}{l}D_{\mathrm{p}}^{\mathrm{a}} \\
\left(\mathrm{g} \mathrm{cm}^{-3}\right)\end{array}$} & \multicolumn{3}{|c|}{ Particle size distribution $(\mu \mathrm{m})$} & \multirow{2}{*}{$\begin{array}{l}\mathrm{pH} \\
\mathrm{H}_{2} \mathrm{O}\end{array}$} & \multirow{2}{*}{$\begin{array}{l}\mathrm{OC}^{\mathrm{b}} \\
\left(\mathrm{g} \mathrm{kg}^{-1}\right)\end{array}$} \\
\hline & & $\begin{array}{l}<2 \\
\left(\mathrm{~g} \mathrm{~kg}^{-1}\right)\end{array}$ & $\begin{array}{l}2-50 \\
\left(\mathrm{~g} \mathrm{~kg}^{-1}\right)\end{array}$ & $\begin{array}{l}50-2,000 \\
\left(\mathrm{~g} \mathrm{~kg}^{-1}\right)\end{array}$ & & \\
\hline \multicolumn{7}{|c|}{ Native vegetation } \\
\hline $0-3$ & $2.58^{\mathrm{c}}$ & 775 & 123 & 102 & 5.0 & 29.2 \\
\hline $3-6$ & $2.58^{\mathrm{c}}$ & 764 & 131 & 105 & 5.1 & 24.1 \\
\hline $10-17$ & 2.64 & 792 & 124 & 84 & 5.1 & 18.9 \\
\hline $25-32$ & 2.64 & 773 & 142 & 85 & 5.3 & 14.0 \\
\hline $33-40$ & 2.64 & 775 & 136 & 89 & 5.2 & 12.5 \\
\hline $90-100$ & 2.69 & 782 & 140 & 78 & 5.4 & 6.7 \\
\hline \multicolumn{7}{|l|}{ Pasture } \\
\hline $0-3$ & $2.61^{\mathrm{c}}$ & 679 & 248 & 73 & 7.0 & 28.0 \\
\hline $3-6$ & $2.61^{\mathrm{c}}$ & 722 & 210 & 68 & 5.7 & 20.2 \\
\hline $10-17$ & 2.66 & 737 & 200 & 63 & 5.2 & 16.3 \\
\hline $25-32$ & 2.67 & 669 & 261 & 70 & 5.2 & 15.9 \\
\hline $33-40$ & 2.66 & 698 & 233 & 69 & 5.2 & 15.2 \\
\hline $48-55$ & 2.67 & 696 & 234 & 70 & 5.3 & 14.4 \\
\hline $90-100$ & 2.68 & 728 & 205 & 67 & 5.2 & 6.3 \\
\hline
\end{tabular}

Table 1. Physical and chemical characteristics of the soils studied

The soil under two land uses was studied: (i) under a native vegetation which is a cerrado sensu stricto consisting of the association of tree and shrub species with the development of an herbaceous strata during the wet season (Ribeiro and Walter, 1998) and (ii) under a low productivity pasture sowed in 1990 with Brachiaria brizantha $c v$. Marandu after clearing the native vegetation in 1989 and lime application at the surface.

\subsection{Sampling and methods}

Because of the very small cohesion of the soil, undisturbed samples were collected by using copper cylinders $13.8 \mathrm{~cm}^{3}$ in volume to investigate the water retention according to the water potential $(\Psi$, in $\mathrm{hPa})$ at $0-3,3-6,25-32,33-40 \mathrm{~cm}$ where differences of structures were shown by Balbino et al. (2002b) between the soil under native vegetation and the one under pasture. As no difference of structure was recorded by Balbino et al. (2002b) from 50- to 130cm depth, we collected other undisturbed samples in the same way at 90-97-cm depth. Water content at $-10,-33,-100,-330,-1000$ and $-15000 \mathrm{hPa}$ was measured using pressure apparatus. The samples were placed still in their cylinder on a paste made of $<2-\mu \mathrm{m}$ particles of kaolinite to establish continuity of water between the soils material and the membrane or the porous plate of the apparatus (Bruand et al., 1996). The paste enabled the rewet of the samples by capillarity until equilibrium was reached prior applying the pressure. In that state, the samples were considered as being in equilibrium with $\Psi=-1 \mathrm{hPa}$. The water content (W, in $\mathrm{g} \mathrm{g}^{-1}$ ) was expressed with respect to the dry mass of the sample after oven-drying at $105^{\circ} \mathrm{C}$ for $24 \mathrm{~h}$. Six samples were used to determine the mean water content at every water potential. 
Other undisturbed samples $7 \times 5 \times 10 \mathrm{~cm}^{3}$ in volume were collected at $0-7-, 25-32-$, 33-40- and 90-97-cm depth and impregnated with a polyester resin that was diluted with styrene monomer. Thin sections $4.5 \times 6 \mathrm{~cm}^{2}$ were produced and polished with diamond grains of decreasing size (FitzPatrick, 1984). They were coated with carbon prior examination in scanning electron microscopy using the backscattered electron mode.

The saturated hydraulic conductivity $\left(K_{\mathrm{s}}\right)$ was determined on samples collected in duplicate at 0-7-, 25-32-, 33-40- and 90-97-cm depth with cylinders $929 \mathrm{~cm}^{3}$ in volume (H7 cm, 13 $\mathrm{cm}$ ) except under pasture at $0-7-\mathrm{cm}$ depth where four samples were collected because of structure variation due to the presence of Brachiaria clumps. After saturation, the samples were submitted to a constant hydraulic head gradient in a column maintained at a temperature of $20{ }^{\circ} \mathrm{C}$. The water flow was per ascensum with the sample turned upside down. $K_{\mathrm{s}}$ was determined by using five different hydraulic head gradients, the volume of water passed throughout the sample being measured after $2 \mathrm{~h}$ at every head gradient applied. The unsaturated hydraulic was determined by applying the Wind (1968) evaporation method to undisturbed samples $1236 \mathrm{~cm}^{3}$ in volume $(H 7 \mathrm{~cm}, 15 \mathrm{~cm})$. The samples were collected at the same depth than for $K_{\mathrm{s}}$ determination and with similar number of replicates. They were saturated in the same way than for $K_{\mathrm{s}}$ determination (Wendroth et al., 1993 and Tamari et al., 1993 ). The mathematical procedures used to calculate $K$ from Darcy's law, and the procedure used to fit Van Genuchten (1980) model are described in the work of Mohrath et al. (1997). According to the experimental conditions, $K(\Psi)$ was established for $-900 \leq \Psi \leq-50 \mathrm{hPa}$. The soil contained in the cylinders used for saturated and unsaturated hydraulic conductivity measurements was oven dried at $105^{\circ} \mathrm{C}$ for $24 \mathrm{~h}$ to calculate the bulk density $\left(D_{\mathrm{b}}\right)$ for every cylinder.

\section{Results}

\subsection{Structure description in the field}

The soil under the native vegetation showed a well-developed crumb macrostructure from 0 to $7-\mathrm{cm}$ depth, a moderate to weak crumb macrostructure from 7 to $20 \mathrm{~cm}$, a weak medium polyedral macrostructure from $20-$ to $40-\mathrm{cm}$ depth and no macrostructure from $40-$ to $100-\mathrm{cm}$ depth with numerous large channels and chambers resulting from termite activity. Microaggregates were observed in the first $30 \mathrm{~cm}$ located in biological channels and vughs. Deeper in the soil, microaggregation was generalised with well-developed sub-millimetric near-spherical microaggregates. Under the pasture, the soil showed a sealed surface between the Brachiaria clumps and moderate horizontal platy structure from $0-$ to $3-\mathrm{cm}$ depth, a small to medium well blocky structure from $3-$ to $18-\mathrm{cm}$ depth, a weak subangular blocky macrostructure from 18 - to $46-\mathrm{cm}$ depth and no macrostructure from 46- to $100-\mathrm{cm}$ depth. Microaggregation was much less developed than under native vegetation in the first top $50 \mathrm{~cm}$ and located mainly in biological channels and vughs. Deeper in the soil, microaggregation was generalised as it was under native vegetation with numerous large channels and chambers resulting from termite activity.

\subsection{Scanning electron microscopy}

Under native vegetation, backscattered electron scanning images (BESI) showed at 0-7-, 2532- and 33-40-cm depth dense areas with closely packed microaggregates 50 to $300 \mu \mathrm{m}$ in diameter associated to other areas with similar microaggregates in loose packing (Fig. 1A). 
The proportion of the two types of areas appeared to be similar from 0 - to $40-\mathrm{cm}$ depth. At 90-97-cm depth, BESI showed a loose packing of microaggregates 50-300 $\mu \mathrm{m}$ in diameter (Fig. 1B) and locally a few areas with similar microaggregates in close packing. Under Pasture, BESI showed fluffy microaggregates $500-2000 \mu \mathrm{m}$ in diameter in a close packing at $0-10-\mathrm{cm}$ depth (Fig. 1c). Deeper in the soil, BESI showed a microstructure similar to the microstructure recorded under native vegetation but with a greater proportion of dense areas with microaggregates $50-300 \mu \mathrm{m}$ in diameter closely packed (Fig. 1d). At 33-40-cm depth, about three quarters of the surface area of the thin section corresponded to these dense areas.
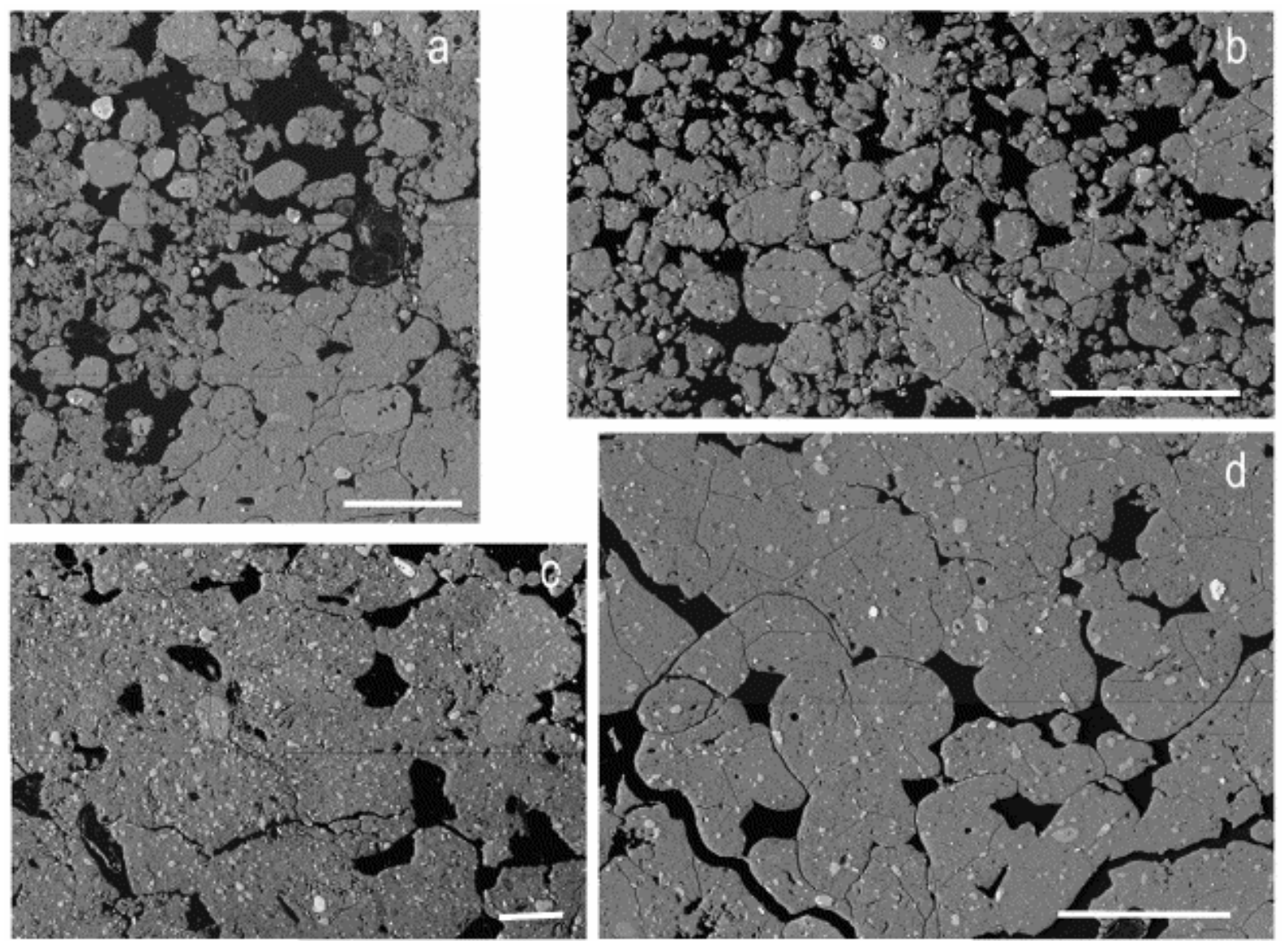

Fig. 1. Backscattered electron scanning images from the thin sections showing microaggregates 50-300 $\mu \mathrm{m}$ in diameter in different packing at 33-40 cm depth under native vegetation (a), microaggregates 50-300 $\mu \mathrm{m}$ in diameter in a loose packing at 90-97 cm depth under native vegetation (b), microaggregates 500-2000 $\mu \mathrm{m}$ in diameter grouped together at 0-7 cm depth under pasture (c) and microaggregates 50-300 $\mu \mathrm{m}$ in diameter closely packed at 33-40 cm depth under pasture (d). The black areas are voids occupied by resin, the light grey areas are quartz and the heterogeneous dark areas correspond to clay particles (scale bar: $500 \mu \mathrm{m}$ ).

\subsection{Water retention properties using the pressure apparatus}

Water contents at the water potential studied are shown in Fig. 2. At $-1 \mathrm{hPa}$, the soil under native vegetation retained much more water than the soil under pasture from $0-$ to $40-\mathrm{cm}$ depth (Fig. 2). At $-10 \mathrm{hPa}$, the soil under native vegetation still retained more water than under pasture from 0 - to $32-\mathrm{cm}$ depth but the difference of water retained was smaller than at $-1 \mathrm{hPa}$. At 33-40-cm depth, the difference of water retained was similar to the one recorded at $-10 \mathrm{hPa}$. Then at smaller water potential, the soil under native vegetation and pasture 
showed similar water retention properties. At 90-100-cm depth, the water contents were similar under native vegetation and pasture.
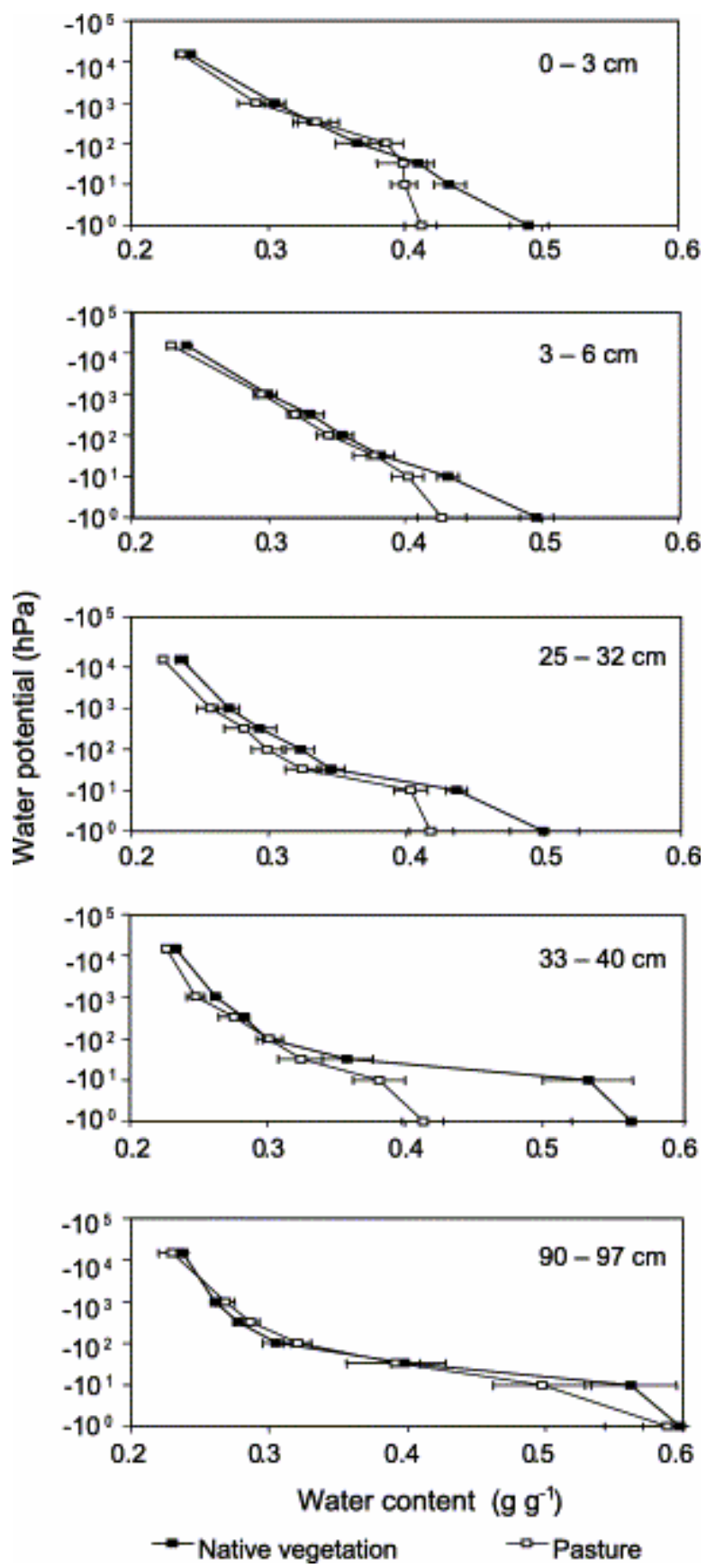

Fig. 2. Water retention properties measured using the small undisturbed samples collected under native vegetation and pasture (horizontal area \pm standard deviation).

\subsection{Saturated and unsaturated hydraulic conductivity}

The saturated hydraulic conductivity $\left(K_{\mathrm{s}}\right)$ ranged from $2.1 \times 10^{-5}$ to $6.6 \times 10^{-5} \mathrm{~m} \mathrm{~s}^{-1}$ under native vegetation and from $0.6 \times 10^{-5}$ to $16.9 \times 10^{-5} \mathrm{~m} \mathrm{~s}^{-1}$ under pasture (Table 2). Under native vegetation, $K_{\mathrm{s}}$ significantly increased from $0-7-\mathrm{cm}$ depth to $33-40-\mathrm{cm}$ depth, then there was no significant difference $(P=0.95)$ at 33-40- and 90-97-cm depth. Under pasture, the smallest $K_{\mathrm{s}}$ was recorded at $0-7-\mathrm{cm}$ depth $\left(0.5-0.6 \times 10^{-5} \mathrm{~m} \mathrm{~s}^{-1}\right)$. Between the Brachiaria clumps, $K_{\mathrm{s}}$ was smaller than under the clumps $\left(2.0 \times 10^{-5}-2.3 \times 10^{-5} \mathrm{~m} \mathrm{~s}^{-1}\right)$. Deeper in the soil, $K_{\mathrm{s}}$ was 
significantly greater $(P=0.95)$ than at $0-7-\mathrm{cm}$ depth between the Brachiaria clumps but it was not significantly different at every depth because of the variability between replicates.

\begin{tabular}{lcl}
\hline Depth $(\mathrm{cm})$ & $K_{\mathrm{s}}\left(10^{-5} \mathrm{~m} \mathrm{~s}^{-1}\right)$ & $D_{\mathrm{b}}\left(\mathrm{g} \mathrm{cm}^{-3}\right)$ \\
\hline Native vegetation & & \\
$0-7$ & 2.1 & 1.06 \\
$0-7$ & 3.6 & 1.12 \\
$25-32$ & 3.2 & 1.17 \\
$25-32$ & 4.3 & 1.18 \\
$33-40$ & 5.3 & 1.05 \\
$33-40$ & 6.6 & 1.10 \\
$90-97$ & 4.0 & 0.99 \\
$90-97$ & 6.6 & 0.98 \\
& & \\
Pasture & & \\
$0-7^{\mathrm{a}}$ & 0.5 & 1.24 \\
$0-7^{\mathrm{a}}$ & 0.6 & 1.19 \\
$0-7^{\mathrm{b}}$ & 2.0 & 1.23 \\
$0-7^{\mathrm{b}}$ & 2.3 & 1.06 \\
$25-32$ & 7.9 & 1.21 \\
$25-32$ & 5.3 & 1.24 \\
$33-40$ & 6.0 & 1.23 \\
$33-40$ & 5.9 & 1.24 \\
$90-97$ & 16.9 & 0.96 \\
$90-97$ & 6.0 & 1.12 \\
\hline
\end{tabular}

${ }^{\text {a }}$ Between Brachiaria clumps.

${ }^{\mathrm{b}}$ Under Brachiaria clumps.

Table 2. Saturated hydraulic conductivity $\left(K_{\mathrm{s}}\right)$ and bulk density $\left(D_{\mathrm{b}}\right)$

The $K(\Psi)$ curves are shown in Fig. 3 and the parameters of the Van Genuchten (1980) model that were calculated are given in Table 3. As a whole, the curves are similar at every depth between the two land uses because of the great variability of the individual calculated values of $K(\Psi)$ around the mean curve that are shown in Fig. 3. We also calculated $K$ at -50 and $-900 \mathrm{hPa}$ that were approximately the maximum and the minimum $\Psi$ for most samples (Table 4). For $\Psi=-50 \mathrm{hPa}, K$ ranged from $0.3 \times 10^{-7}$ to $103.1 \times 10^{-7} \mathrm{~m} \mathrm{~s}^{-1}$ and for $\Psi=-900 \mathrm{hPa}$, from $0.9 \times 10^{-10}$ to $65.2 \times 10^{-10} \mathrm{~m} \mathrm{~s}^{-1}$. At -50 and $-900 \mathrm{hPa}, K$ showed an upward trend from $0-7$ - to 90-97-cm depth under native vegetation and pasture. At every depth, the value of $K$ can be considered as similar under native vegetation and pasture because of the great variability between replicates. 


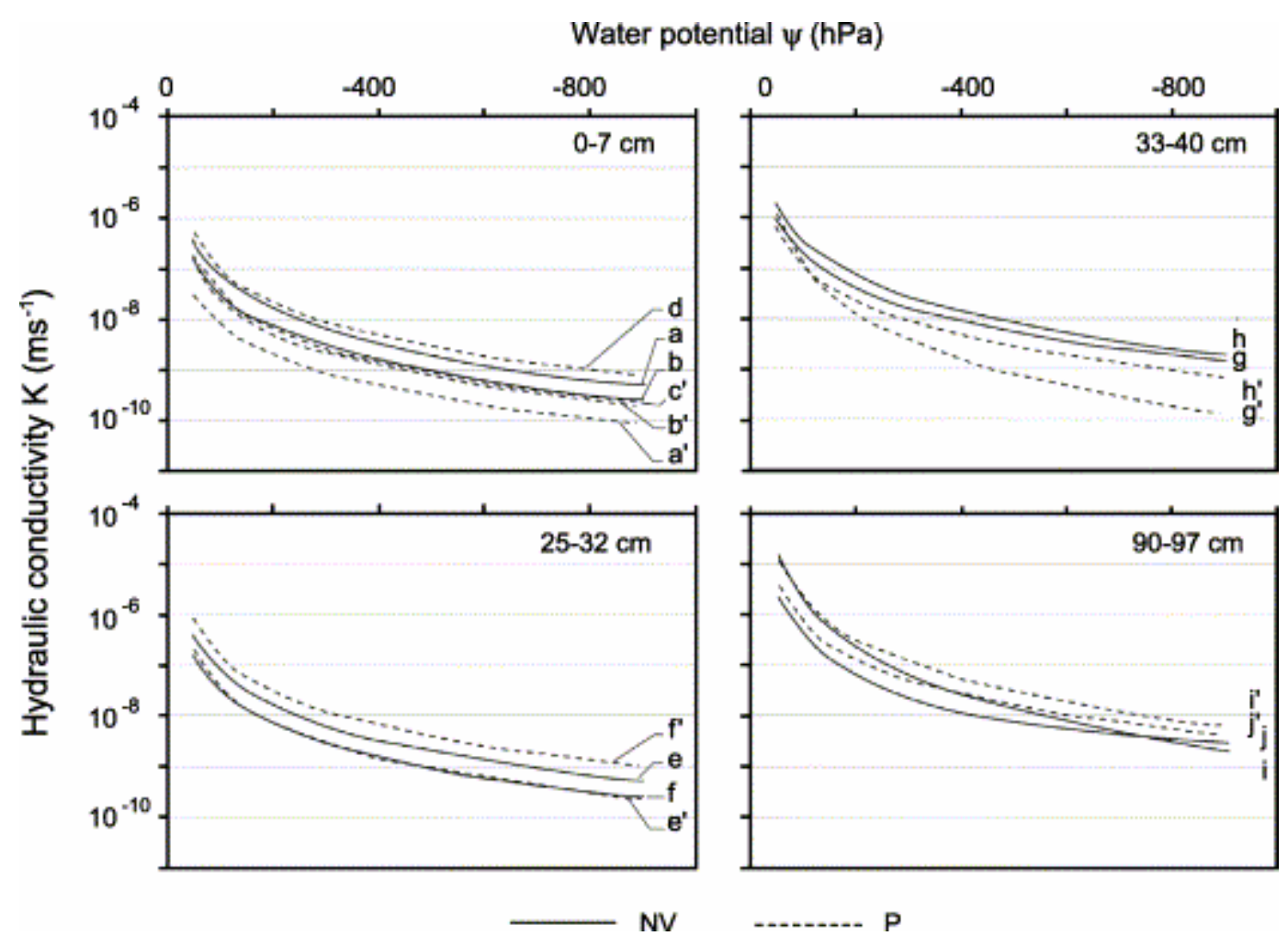

Fig. 3. Hydraulic conductivity, $K(\Psi)$, determined by using the evaporation method on core samples from the soil under native vegetation and under Pasture. $\left(a, b, \ldots, i^{\prime}\right.$ and $j^{\prime}$ see $\left.\underline{\text { Table } 3}\right)$.

\begin{tabular}{|c|c|c|c|c|c|c|}
\hline Depth $(\mathrm{cm})$ & $D_{\mathrm{b}}{ }^{\mathrm{a}}\left(\mathrm{g} \mathrm{cm}^{-3}\right)$ & $\theta_{\mathrm{S}}^{\mathrm{b}}\left(\mathrm{m}^{3} \mathrm{~m}^{-3}\right)$ & $\theta_{\mathrm{r}}^{\mathrm{c}}\left(\mathrm{m}^{3} \mathrm{~m}^{-3}\right)$ & $n^{\mathrm{d}}$ & $\alpha^{e}\left(m^{-1}\right)$ & $K_{\mathrm{s}}{ }^{\mathrm{f}}\left(10^{-5} \mathrm{~m} \mathrm{~s}^{-1}\right)$ \\
\hline \multicolumn{7}{|c|}{ Native vegetation } \\
\hline $0-7$ (a) & 1.03 & 0.596 & 0.349 & 1.63 & 7.57 & 6.0 \\
\hline $0-7$ (b) & 1.07 & 0.583 & 0.295 & 1.48 & 12.53 & 9.0 \\
\hline $25-32(\mathrm{e})$ & 1.11 & 0.557 & 0.298 & 1.57 & 14.00 & 37.9 \\
\hline $25-32$ (f) & 1.07 & 0.591 & 0.259 & 1.42 & 21.62 & 115.3 \\
\hline $33-40(\mathrm{~g})$ & 1.07 & 0.557 & 0.279 & 1.53 & 14.30 & 68.7 \\
\hline $33-40(h)$ & 1.01 & 0.566 & 0.261 & 1.73 & 8.85 & 34.0 \\
\hline $90-97$ (i) & 0.99 & 0.579 & 0.289 & 3.23 & 3.48 & 18.7 \\
\hline $90-97(\mathrm{j})$ & 1.02 & 0.619 & 0.257 & 1.65 & 11.04 & 71.3 \\
\hline \multicolumn{7}{|l|}{ Pasture } \\
\hline $0-7\left(a^{\prime}\right)^{g}$ & 1.28 & 0.508 & 0.248 & 1.24 & 3.32 & 0.3 \\
\hline $0-7\left(b^{\prime}\right)^{\mathrm{g}}$ & 1.13 & 0.566 & 0.289 & 1.40 & 7.80 & 2.9 \\
\hline $0-7\left(c^{\prime}\right)^{h}$ & 1.08 & 0.581 & 0.328 & 1.58 & 8.09 & 3.1 \\
\hline $0-7\left(d^{\prime}\right)^{\mathrm{h}}$ & 1.14 & 0.561 & 0.294 & 1.48 & 7.86 & 10.6 \\
\hline $25-32\left(\mathrm{e}^{\prime}\right)$ & 1.24 & 0.532 & 0.324 & 1.71 & 6.42 & 1.9 \\
\hline $25-32\left(\mathrm{f}^{\prime}\right)$ & 1.20 & 0.549 & 0.304 & 1.52 & 15.09 & 60.5 \\
\hline $33-40\left(g^{\prime}\right)$ & 1.14 & 0.581 & 0.319 & 3.21 & 7.59 & 14.1 \\
\hline $33-40\left(\mathrm{~h}^{\prime}\right)$ & 1.23 & 0.534 & 0.309 & 1.63 & 12.85 & 28.8 \\
\hline $90-97\left(\mathrm{i}^{\prime}\right)$ & 1.10 & 0.529 & 0.284 & 2.18 & 4.35 & 29.7 \\
\hline $90-97\left(\mathrm{j}^{\prime}\right)$ & 1.02 & 0.577 & 0.262 & 1.61 & 9.25 & 80.4 \\
\hline
\end{tabular}

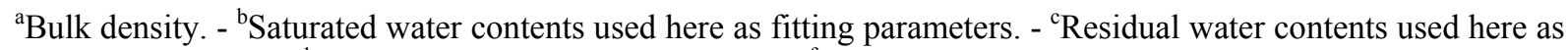
fitting parameters. - ${ }^{\mathrm{d}, \mathrm{e}}$ Are empirical fitting parameters. - ${ }^{\mathrm{f}}$ Saturated hydraulic conductivity calculated for $\Psi=0$. ${ }^{\mathrm{g}}$ Between Brachiaria clumps. - ${ }^{\mathrm{h}}$ Under Brachiaria clumps.

Table 3. Parameters of the Van Genuchten (1980) model for the $K(\Psi)$ curves (letters in parentheses enable samples identification, see Fig. 3) 


\begin{tabular}{lcc}
\cline { 2 - 3 } & $\begin{array}{c}-50 \mathrm{hPa} \\
\left(10^{-7} \mathrm{~m} \mathrm{~s}^{-1}\right)\end{array}$ & $\begin{array}{c}-900 \mathrm{hPa} \\
\left(10^{-10} \mathrm{~m} \mathrm{~s}^{-1}\right)\end{array}$ \\
\hline Native vegetation & & \\
$0-7(\mathrm{a})$ & 3.8 & 5.1 \\
$0-7(\mathrm{~b})$ & 1.5 & 2.4 \\
$25-32(\mathrm{e})$ & 5.6 & 7.9 \\
$25-32(\mathrm{f})$ & 5.1 & 8.8 \\
$33-40(\mathrm{~g})$ & 9.2 & 13.7 \\
$33-40(\mathrm{~h})$ & 16.9 & 19.3 \\
$90-97(\mathrm{i})$ & 143.1 & 19.5 \\
$90-97(\mathrm{j})$ & 19.9 & 25.1 \\
& & \\
Pasture & & \\
$0-7\left(\mathrm{a}^{\prime}\right)^{\mathrm{a}}$ & 0.3 & 0.9 \\
$0-7\left(\mathrm{~b}^{\prime}\right)^{\mathrm{a}}$ & 1.0 & 2.0 \\
$0-7\left(\mathrm{c}^{\prime}\right)^{\mathrm{b}}$ & 1.6 & 2.3 \\
$0-7\left(\mathrm{~d}^{\prime}\right)^{\mathrm{b}}$ & 4.7 & 8.0 \\
$25-32\left(\mathrm{e}^{\prime}\right)$ & 1.9 & 2.3 \\
$25-32\left(\mathrm{f}^{\prime}\right)$ & 7.1 & 10.7 \\
$33-40\left(\mathrm{~g}^{\prime}\right)$ & 10.5 & 1.4 \\
$33-40\left(\mathrm{~h}^{\prime}\right)$ & 5.6 & 7.2 \\
$90-97\left(\mathrm{i}^{\prime}\right)$ & 103.1 & 43.2 \\
$90-97\left(\mathrm{j}^{\prime}\right)$ & 31.6 & \\
\hline
\end{tabular}

${ }^{a}$ Between Brachiaria clumps.

${ }^{\mathrm{b}}$ Under Brachiaria clumps.

Table 4. Hydraulic conductivity $(K)$ calculated for -50 and $-900 \mathrm{hPa}$ (letters in parentheses enable samples identifications, see Table 3 and Fig. 3 )

\subsection{Bulk density}

The values of $D_{\mathrm{b}}$ measured with $929 \mathrm{~cm}^{3}$ cylinders showed that under native vegetation, $D_{\mathrm{b}}$ roughly increased from $0-7-\mathrm{cm}$ depth $\left(1.06-1.12 \mathrm{~g} \mathrm{~cm}^{-3}\right)$ to $25-32-\mathrm{cm}$ depth $(1.17-1.18 \mathrm{~g}$ $\left.\mathrm{cm}^{-3}\right)$, then decreased to $90-97-\mathrm{cm}$ depth $\left(0.99-0.98 \mathrm{~g} \mathrm{~cm}^{-3}\right)$ (Table 2). Under pasture, $D_{\mathrm{b}}$ was variable at $0-7-\mathrm{cm}$ depth $\left(1.06-1.24 \mathrm{~g} \mathrm{~cm}^{-3}\right)$. The smallest $D_{\mathrm{b}}$ was recorded at $90-97-\mathrm{cm}$ depth. When we compare the soil under native vegetation and under pasture, $D_{\mathrm{b}}$ were greater under pasture than under vegetation at $0-7-$ and 33-40-cm depth. On the other hand, the values of $D_{\mathrm{b}}$ measured with $1236-\mathrm{cm}^{3}$ cylinders showed that under native vegetation, there was small variation of $D_{\mathrm{b}}$ from the surface to $90-97-\mathrm{cm}$ depth $\left(0.99-1.02 \mathrm{~g} \mathrm{~cm}^{-3}\right.$ ) (Table 3). Under pasture, $D_{\mathrm{b}}$ was greater than under native vegetation. The greatest $D_{\mathrm{b}}$ was measured in the $0-7-\mathrm{cm}$ layer $\left(1.28 \mathrm{~g} \mathrm{~cm}^{-3}\right)$ but that layer showed a $D_{\mathrm{b}}$ highly variable. If we except the $1.28 \mathrm{~g} \mathrm{~cm}^{-3}$ that was recorded in the $0-7-\mathrm{cm}$ layer, $D_{\mathrm{b}}$ was great at $25-32-\mathrm{cm}$ depth $(1.20$ $\left.1.24 \mathrm{~g} \mathrm{~cm}^{-3}\right)$ with close values at 33-40-cm depth $\left(1.14-1.23 \mathrm{~g} \mathrm{~cm}^{-3}\right)$ and the smaller values at $90-97-\mathrm{cm}$ depth $\left(1.10-1.02 \mathrm{~g} \mathrm{~cm}^{-3}\right)$.

The mean $D_{\mathrm{b}}$ was calculated at every depth under native vegetation and pasture using the whole set of data (Table 5). Results clearly showed that $D_{\mathrm{b}}$ at $0-7-\mathrm{cm}$ depth was smaller under native vegetation than between the Brachiaria clumps in the pasture with no significant 
difference $(P=0.95)$ with $D_{\mathrm{b}}$ under the clumps. At 23-32- and 33-40-cm depth, $D_{\mathrm{b}}$ was significantly smaller $(P=0.95)$ under native vegetation than under pasture. At $90-97-\mathrm{cm}$ depth, results showed no significant difference $(P=0.95)$ between native vegetation and pasture.

\begin{tabular}{|c|c|c|}
\hline \multirow[t]{2}{*}{ Depth $(\mathrm{cm})$} & \multicolumn{2}{|l|}{$D_{\mathrm{b}}$} \\
\hline & $\begin{array}{l}\text { Mean } \\
\left(\mathrm{g} \mathrm{cm}^{-3}\right)\end{array}$ & $\begin{array}{l}\text { Standard } \\
\text { deviation } \\
\left(\mathrm{g} \mathrm{cm}^{-3}\right)\end{array}$ \\
\hline \multicolumn{3}{|c|}{ Native vegetation } \\
\hline $0-7$ & 1.07 & 0.04 \\
\hline $25-32$ & 1.13 & 0.05 \\
\hline $33-40$ & 1.06 & 0.04 \\
\hline $90-97$ & 1.00 & 0.02 \\
\hline \multicolumn{3}{|l|}{ Pasture } \\
\hline $0-7^{\mathrm{a}}$ & 1.21 & 0.06 \\
\hline $0-7^{\mathrm{b}}$ & 1.13 & 0.08 \\
\hline $25-32$ & 1.22 & 0.02 \\
\hline $33-40$ & 1.21 & 0.05 \\
\hline $90-97$ & 1.05 & 0.07 \\
\hline
\end{tabular}

Table 5. Mean bulk densities $\left(D_{\mathrm{b}}\right)$ measured with the $929-$ and $1236-\mathrm{cm}^{3}$ cylinders

\section{Discussion}

\subsection{Water retention and land use}

Comparison of the water retention between the two land uses showed that the amount of water retained at -1 and $10 \mathrm{hPa}$ was smaller under pasture than under native vegetation from 0 - to $40-\mathrm{cm}$ depth (Fig. 2). Such a difference of the water retention properties is explained by the difference of structure between the two land uses. Indeed, field descriptions and observations in microscopy showed that (i) the microstructure was less developed under pasture than under native vegetation and (ii) the proportion of microaggregates in close packing was greater under pasture than under native vegetation (Fig. 1). Thus, the smaller volume of pores that results from that change of structure is responsible for the difference of water retained at -1 and $-10 \mathrm{hPa}$ between native vegetation and pasture. The variation of structure was also consistent with the difference of $D_{\mathrm{b}}$ recorded (Table 5), a decrease in $D_{\mathrm{b}}$ corresponding to an increase in the microaggregation development. For $\Psi \leq-33 \mathrm{hPa}$, there was no significant $(P=0.95)$ difference of water retained at $0-3-, 3-6-, 25-32-$ and 33-40-cm depth, thus showing that the difference of microstructure recorded between native vegetation and pasture did not have any measurable consequence on the water retention properties. Finally, at 90-97$\mathrm{cm}$ depth, there was no significant difference $(P=0.95)$ of water content for $-15000 \leq \Psi \leq-1$ 
$\mathrm{hPa}$. This was consistent with the lack of difference of structure and bulk density at that depth between the two land uses (Table 5).

\subsection{Prediction of the water retention properties and variation of structure}

Using data from the literature and considering that differences of structure were very small between Ferralsols, Balbino et al. (2002a) established pedotransfer functions for Ferralsols from the Brazilian Savannah zone between the gravimetric water content $(W)$ at -15000 , -330 and $-100 \mathrm{hPa}$ and the clay content (\% clay) alone:

$W=0.287(\%$ clay $)+1.4$ at $\Psi=-15,000 \mathrm{hPa}$

$W=0.330(\%$ clay $)+5.8$ at $\Psi=-330 \mathrm{hPa}$

$W=0.331(\%$ clay $)+8.3$ at $\Psi=-100 \mathrm{hPa}$

We discussed the validity of these pedotransfer function using our results. We calculated the mean error of prediction (MEP) and the standard deviation of prediction (SDP) as follows (Wösten et al., 2001):

$$
\begin{aligned}
& \text { MEN }=\frac{\sum_{n=1}^{W}\left(W_{x}-W_{2}\right)}{n-1}
\end{aligned}
$$

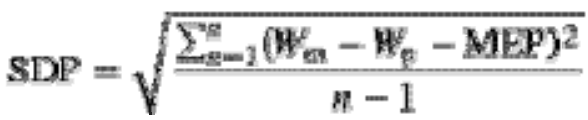

where $W_{\mathrm{m}}$ is the measured gravimetric water content, $W_{\mathrm{p}}$ is the predicted gravimetric water content and $n$ is the number of horizons $(n=11)$. The sign of MEP indicates whether the pedotransfer function overestimated (negative) or underestimated (positive) the water content, whereas SDP measures the precision of the predictions. Results gave $\mathrm{MEP}=0.008,-0.001$ and $-0.002 \mathrm{~g} \mathrm{~g}^{-1}$ at water potentials of $-15000,-330$ and $-100 \mathrm{hPa}$, respectively this indicating very small underestimation at $-15000 \mathrm{hPa}$ and very small overestimation at -330 and -100 $\mathrm{hPa}$. Results gave SDP $=0.011,0.025$ and $0.031 \mathrm{~g} \mathrm{~g}^{-1}$ at $-15000,-330$ and $-100 \mathrm{hPa}$, respectively. The decrease in the precision when $\Psi$ increases would be related to a variation of the water retained because of the change of structure that was recorded on clearing for pasture. This points out the necessity to take parameters describing soil structure as predictor even for soils that show little difference of structure in the field.

\subsection{Saturated and unsaturated hydraulic conductivity}

The smallest $K_{\mathrm{s}}$ and $K$ at -50 and $-900 \mathrm{hPa}$ were recorded under pasture at $0-7-\mathrm{cm}$ depth between the Brachiaria clumps. These value of $K_{\mathrm{s}}$ and $K$ were related to the seal surface and the horizontal platy structure, as well as the close packing of the microaggregates (Fig. 1c). At 0-7-cm depth under Brachiaria clumps and at the other depths, there was no significant difference $(P=0.95)$ of $K_{\mathrm{s}}$ between the soil under pasture and the soil under native vegetation (Table 3). This lack of difference when variation of microaggregate packing was recorded with depth and land use might be related to the contribution of the biological pores to water flow. At -50 and $-900 \mathrm{hPa}$, the greatest $K$ was recorded at $90-97-\mathrm{cm}$ depth under pasture and 
native vegetation (Table 4). This value of $K$ would be related to the greater development of microaggregation recorded at 90-97-cm depth (Fig. 1).

\section{Conclusion}

Our results showed that clearing the native vegetation for pasture led to a significant change of the structure for the clay Ferralsol studied. That change consisted of a decrease in the microaggregation development and a close arrangement of the microaggregates remaining that was particularly visible at $33-40-\mathrm{cm}$ depth under pasture. That evolution of the structure shown in the field and in microscopy was consistent with the bulk densities recorded at every depth under native vegetation and pasture. That evolution of the structure led to a decrease in the water retained at -1 and $-10 \mathrm{hPa}$ from 0 - to $40-\mathrm{cm}$ depth under pasture. The greatest difference of water retained between native vegetation and pasture was recorded at $33-40-\mathrm{cm}$ depth where a much greater proportion of areas with microaggregates in close packing was recorded under pasture. For smaller water potential, we did not record any difference of water retained at every depth between native vegetation and pasture. The pedotransfer functions proposed for Brazilian Ferralsols and established with the clay content as single predictor gave pretty good results but the precision of the estimation decreased when the water potential increased. This decrease in the precision was related to the lack of predictor taking structure into account. The values of $K_{\mathrm{s}}$ and $K(\Psi)$ showed an upward trend with depth under native vegetation and pasture. Except at $0-7-\mathrm{cm}$ depth between the Brachiaria clumps in the pasture where smaller $K_{\mathrm{s}}$ and $K(\Psi)$ than at the other depth was recorded whatever land use, we did not record any significant difference of $K_{\mathrm{s}}$ and $K(\Psi)$ at every depth between native vegetation and pasture. The upward trend shown by the hydraulic conductivity with depth was related to the increase in the development of microaggregation with depth.

\section{Acknowledgements}

We thank the Empresa Brasileira de Pesquisa Agropecuária (EMBRAPA), the Institut National de la Recherche Agronomique (INRA) and the Institut de Recherche pour le Développement (IRD) for their financial support of the L.C. Balbino's work in France. We thank also Hervé Gaillard, Laurent Raison, Loïc Prud'homme, and Sacha Desbourdes (INRA Orléans) for their help in the laboratory and Sebastião Araujo (EMBRAPA Arroz e Feijão).

\section{References}

1. Assad, E.D., Sano, E.E., Masutomo, R., Castro, L.H.R. and Silva, F.A.M., 1993. Veranicos na região dos cerrados brasileiros: freqüência e probabilidade de ocorrência. Pesquisa Agropecuária Brasileira 28, pp. 993-1002.

2. Assouline, S., Tavares-Filho, J. and Tessier, D., 1997. Effect of compaction on soil physical and hydraulic properties: experimental results and modeling. Soil Science Society of America Journal 61, pp. 390-398.

3. Balbino, L.C., Bruand, A., Brossard, M. and Guimarães, M.F., 2001. Comportement de la phase argileuse lors de la dessiccation dans des Ferralsols microagrégés du Brésil : rôle de la microstructure et de la matière organique. Comptes Rendus de l'Académie des Sciences 332, pp. 673-680.

4. Balbino, L.C., Brossard, M., Leprun, J.C. and Bruand, A., 2002. Mise en valeur des Ferralsols de la région du Cerrado (Brésil) et évolution de leurs propriétés physiques: une étude bibliographique. Etude et Gestion des Sols 9, pp. 83-104. 
5. Balbino, L.C., Bruand, A., Brossard, M., Grimaldi, M., Hajnos, M. and Guimarães, M.F., 2002. Changes in porosity and microaggregation in clayey Ferralsols of the Brazilian Cerrado on clearing for pasture. European Journal of Soil Science 53, pp. 219-230.

6. Beutler, A.N., Silva, M.L.N., Curi, N., Ferreira, M.M., Cruz, J.C. and Pereira Filho, I.A., 2001. Resistência à penetração e permeabilidade de Latossolo-vermelho distrófico típico sob sistema de manejo na região dos Cerrados. Revista Brasileira de Ciência do Solo 25, pp. 167-177.

7. Brewer, R., 1964. Fabric and Mineral Analysis of Soils., Wiley, New York.

8. Bruand, A., Duval, O., Gaillard, H., Darthout, R. and Jamagne, M., 1996. Variabilité des propriétés de rétention en eau des sols: importance de la densité apparente. Etude et Gestion des Sols 3, pp. 27-40.

9. Chauvel, A., Grimaldi, M. and Tessier, D., 1991. Changes in soil pore-space distribution following deforestation and revegetation: an example from the Central Amazon Basin, Brazil. Forest Ecology and Management 38, pp. 259-271.

10. Dardenne, M.A. and Faria, A., 1986. Estratigrafia do Grupo Paranoá na Região do Alto Paraíso-GO. In: 2nd Simpósio de geologia do Centro-Oeste. Geologia do préCambiano, Ata, 28 a 31 de maio de 1985, Universidade Federal de Gois Goiânia-GO, pp. 65-71.

11. EMBRAPA, 1999. Centro Nacional de Pesquisa de solos (Rio de Janeiro, RJ). Sistema brasileiro de classificação de solos. Embrapa Produção de Informação, Embrapa Solos, Brasília, DF.

12. Ferreira, M.M., Fernandes, B. and Curi, N., 1999. Influência da mineralogia da fração argila nas propriedades fisica de latossolos da região sudeste do Brasil. Revista Brasileira de Ciência do Solo 23, pp. 515-524.

13. FitzPatrick, E.A., 1984. Micromorphology of Soils., Chapman \& Hall, London.

14. Frizzone, J.A. and Sobrinho, F.C., 1982. Condutividade hidraulica de um solo de cerrado não saturado Latossolo-vermelho escura alico. Cientifica 10, pp. 49-56.

15. Hartmann, C., 1991. Evolution et comportement de sols sablo-argileux ferrallitiques sous culture de palmiers à huile: Cas de la plantation R. Michaux à Dabou (Côte d'Ivoire). Thèse de doctorat, Université de Paris VI.

16. ISSS Working Group R.B., 1998. World reference base for soil resources: introduction. In: , Deckers, J.A., Nachtergaele, F.O. and Spaargaren, O.C., Editors, 1998. International Society of Soil Science (ISSS) (1st ed.), ISRIC-FAO-ISSS-Acco., Leuven 84 p. .

17. Kubiena, M.L., 1950. Zur micromorphologie der braunen and roten tropenboden. In: Transactions of the 4th International Congress of Soil Science, Amsterdam vol. 1, pp. 304-307.

18. Mohrath, D., Bertuzzi, P. and Bruckler, L., 1997. Méthode de Wind, Guide d'utilisation du logiciel, Version., INRA, Avignon.

19. Neufeldt, H., Ayarza, M.A., Resk, D.V.S. and Zech, W., 1999. Distribution of waterstable aggregates and aggregating agents in Cerrado Oxisols. Geoderma 93, pp. 8599.

20. Ribeiro, J.F. and Walter, B.M.T., 1998. Fitofisionomias do bioma Cerrado. In: Sano, S.M. and de Almeida, S.P., Editors, 1998. Cerrado: ambiente E flora, Embrapa CPAC, Planaltina, DF, pp. 89-166.

21. Stone, L.F. and Silveira, P.M., 1978. Condutividade hidráulica de um Latossolo vermelho-amarelo. Pesquisa Agropecuaria Brasileira 35, pp. 1817-1834.

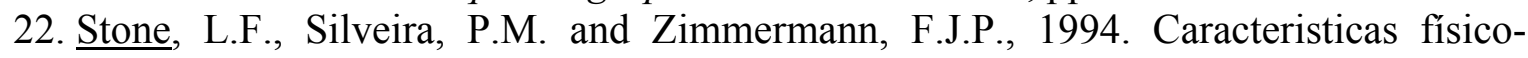
hídrícas e quimicas de um latossolo após adubação e cultivos sucessivos de arroz e 
feijão, sob irrigaçao por aspersão. Revista Brasileira de Ciencia do Solo 18, pp. 533539.

23. Stoner, E.R., Freitas, E., Macedo, J., Mendes, R.C.A, Cardoso, I.M., Amabile, R.F. and Bryant, R.B., 1991. Physical constraints to root growth in savanna Oxisols. In: TropSoils, Bulletin No 91-01, North Carolina State University, Raleigh 28 p. .

24. Tamari, S., Bruckler, L., Halbertsma, J. and Chadoeuf, J., 1993. A simple method for determining soil hydraulic conductivity in the laboratory. Soil Science Society of America Journal 57, pp. 642-651.

25. Tavares Filho, J. 1995. Organisation et comportement de Latosols du Paraná (Brésil). Influence de leur mise en culture. Thèse de Doctorat, Université de Nancy I.

26. Trapnell, C.G. and Webster, R., 1986. Microaggregates in red earths and related soils in East and Central Africa, their classification and occurrence. Journal of Soil Science 37, pp. 109-123.

27. Van Genuchten, M.Th., 1980. A closed-form equation for predicting the hydraulic conductivity of unsaturated soils. Soil Science Society of America Journal 44, pp. 892898.

28. Volpe, E., 1998. Sistemas de recuperação direta de Brachiaria decumbens cv. Basilisk, em Latossolo Vermelho-escuro, na região do Cerrados. Dissertaçao de Mestrado. Universidade Federal do Mato Grosso do Sul. 126 p.

29. Wendroth, O., Ehlers, W., Hopmans, J.W., Kage, H., Halbertsma, J. and Wösten, J.H.M., 1993. Reevaluation of the evaporation method for determining hydraulic functions in unsaturated soils. Soil Science Society of America Journal 57, pp. 14361443.

30. Westerhof, R., Buurman, P., Van Griethuysen, C., Ayarza, M., Vilela, L. and Zech, W., 1999. Aggregation studied by diffraction in relation to plowing and liming in the Cerrado region in Brazil. Geoderma 90, pp. 277-290.

31. Wind, G.P., 1968. Capillary conductivity data estimated by a simple method. In: Rijitema, P.E. and Wassink, H., Editors, 1968. Water in the Insaturated ZoneProc.Wageningen Symp. June 1966 vol. 1, IASAH, Gentbrugge, pp. 181-191.

32. Wösten, J.H.M., Pachepsky, Y.A. and Rawls, W.J., 2001. Pedotransfer functions: bridging the gap between available basic soil data and missing soil hydraulic characteristics. Journal of Hydrology 251, pp. 123-150. 